IZA DP No. 4412

Identities, Conflicting Behavioural Norms and the Importance of J ob Attributes

Giovanni Russo

Edwin van Hooft

September 2009 


\title{
Identities, Conflicting Behavioural Norms and the Importance of Job Attributes
}

\author{
Giovanni Russo \\ Free University Amsterdam \\ and IZA \\ Edwin van Hooft \\ Erasmus University Rotterdam
}

\section{Discussion Paper No. 4412 \\ September 2009}

\author{
IZA \\ P.O. Box 7240 \\ 53072 Bonn \\ Germany \\ Phone: +49-228-3894-0 \\ Fax: +49-228-3894-180 \\ E-mail: iza@iza.org
}

\begin{abstract}
Any opinions expressed here are those of the author(s) and not those of IZA. Research published in this series may include views on policy, but the institute itself takes no institutional policy positions.

The Institute for the Study of Labor (IZA) in Bonn is a local and virtual international research center and a place of communication between science, politics and business. IZA is an independent nonprofit organization supported by Deutsche Post Foundation. The center is associated with the University of Bonn and offers a stimulating research environment through its international network, workshops and conferences, data service, project support, research visits and doctoral program. IZA engages in (i) original and internationally competitive research in all fields of labor economics, (ii) development of policy concepts, and (iii) dissemination of research results and concepts to the interested public.
\end{abstract}

IZA Discussion Papers often represent preliminary work and are circulated to encourage discussion. Citation of such a paper should account for its provisional character. A revised version may be available directly from the author. 
IZA Discussion Paper No. 4412

September 2009

\section{ABSTRACT \\ Identities, Conflicting Behavioural Norms and the Importance of Job Attributes}

The paper empirically expounds the richness of the identity approach to labor market behavior by allowing individuals to experience identity conflict. Specifically, it investigates the relationship between the importance individuals attach to labor-market activities - which is influenced by the identity to which they adhere - and their preferences for job attributes. The analysis shows that individuals who consider labor-market success as instrumental for achieving their life goals tend to attach importance to job characteristics such as pay level and career and training opportunities. Individuals for whom non-labor market activities are important and in conflict with labor market activities are found to attach importance to the possibility of working on a convenient time schedule. Moreover, consistently with the identity approach to labor-market behavior, men appear to resolve the conflict between career and non-work activities in favor of the former. Finally, unobserved factors that increase the desire to work part-time have a negative impact on the likelihood of attaching importance to training and career opportunities offered by the job.

JEL Classification: J22, J24, Z13

Keywords: job attributes, social identity, role conflict, part-time

Corresponding author:

Giovanni Russo

Free University Amsterdam

FEWEB

De Boelelaan 1105

1081 HV Amsterdam

The Netherlands

E-mail: grusso@feweb.vu.nl 


\section{Introduction}

By incorporating a construct borrowed from social psychology into the utility function, the identity-based theory of behavior has widened the range of economic inquiry to encompass behaviors previously difficult to reconcile with standard utility maximization analysis. The augmented economic framework posits that individuals derive utility from compliance with group norms (desired behaviors) because such compliance bolsters their sense of self (self-image). The identity-based economic theory has enriched the economist's toolkit: because new group members, or group members displaying deviant behavior, jeopardize the identity of the other group members (a type of externality) the identity framework can explain why they may be subject to retaliation by incumbent group members (an additional type of externality). These concepts find direct application and can help explain why, despite generally positive attitudes towards parttime workers and female labor-market participation, part-time workers are found to fare worse in the labor market than their full-time colleagues, and women in certain jobs or professions are subject to other forms of retaliation (Fuchs Epstein et al. 1999).

Moreover, in the field of personnel economics, identity manipulation offers firms new tools with which to impress company values on workers (Akerlof and Kranton 2005). Identity also furnishes a coherent framework in which to investigate the infra-household division of labor and the decision to work part-time (Booth and van Ours 2008).

In a theoretical setting depicting a simplified reality, where individuals can hold a limited number of roles, can perform a restricted number of actions, and can belong to only a few groups (with corresponding identities), it is evident that an identity is a powerful addition to an economic model.

However, the real richness and complexity of the inclusion of the identity construct in an economic framework becomes apparent when the model is brought to the data. In fact, an individual's identity is linked to group membership, which in turn is based on observable individual characteristics. Hence, because individuals can be described according to many of their characteristics (such as gender, age, profession, labor market status, income, and so on ), in reality individuals will typically hold multiple identities (consider a professional woman, who may identify with the professional group or may think of herself in terms of her gender). ${ }^{1}$ The complexity level of the analysis can increase

\footnotetext{
${ }^{1}$ Investigation of the mechanisms and factors that influence the salience and the activation of the different identities that an individual may hold would be beyond the scope of this paper.
} 
further, for the behavioral norms prescribed by the different identities that a person holds may, at times, be conflicting.

The introduction of a possible inconsistency among the codes (norms) of the different identities that an individual may hold further enriches the identity-augmented economic framework. Specifically, it envisages the existence of individuals who are driven to achieve labor-market success and who find it difficult to put their drive to good use because of the presence of conflicting (impeding) behavioral norms. To the extent that conflict between behavioral norms interacts with firms' incentive schemes, this new class of individuals may fare badly in the labor market, despite their desire to do otherwise. For example, individuals willing to invest time and effort in labor-market activities but incapable of doing so because of conflicting behavioral norms would have to forgo career and promotions opportunities when firms use long working hours as a screening device (Landers et al. 1996) .

Consequently, individuals committed to labor-market success but experiencing conflicting norms may seek work environments and job characteristics different from those sought by workers who does not experience conflict.

Specifically, in what follows we investigate the relationship between the importance individuals' identities give to labor-market success and the presence of role conflict and the importance attributed to job characteristics using data on self-reported levels of importance attributed to desired job characteristics collected in The Netherlands in 2001 (Van Hooft et al. 2005).

Our findings show that individuals adhering to identities that stress the importance of labor-market success tend to give importance to job characteristics that reflect their investment in labor-market activities: pay, training, and career opportunities. By contrast, individuals that experience conflicting or incoherent norms tend to give importance to job characteristics that can reduce the degree of conflict: favorable working hours, good relationships with colleagues and managers, and a part-time schedule. This is the crux and the novelty of the analysis conducted in this paper.

The paper is organized as follows: the second section presents background information on the different, albeit integrated, approaches to identity. The third section describes the data, and the fourth section illustrates the results. The fifth section concludes. 


\section{Identity, conflicting claims and the importance of job attributes: a roadmap}

The term ‘identity’ denotes a person's self-image. An individual's image of self consists of three integrated groups of elements (Burke 2004, Hitlin 2003, Stets and Burke 2000): those deriving from individual-specific attributes, i.e. values, personality traits, idiosyncratic tastes and interpersonal relationships (personal identity), and those elements deriving from membership of a particular group (social identity theory) or tied to social roles (identity theory). Behavior is mainly driven by the personal identity in interpersonal relations, while social identity becomes increasingly salient in intergroup relations (Halsam 2004). An individual's identity is important because it prescribes (behavioural) norms that circumscribe the life domains that are relatively more important for the sense of self (Akerlof and Kranton 2000, 2005). Individuals assess their standing by measuring their progress against the behavioural norms set by the identity to which they belong in the relevant life domains. Individuals derive satisfaction from the extent to which their behaviour is consistent with the prescribed norm (Nisbett and Ross 1991).

Furthermore, individuals hold roles even when they operate inside a group, because groups tend to be organized (i.e. each group will typically have a leader).

Each individual is assumed to have a personal identity and a set of roles and social identities; each identity informs the individual of who s/he is and of what the identity entails (Halsam 2004).

Labor-market behaviour is a case in point. Identities that stress the importance of labor-market participation do so by setting norms dictating the appropriate proportion of time to be allocated to labor-market and non-labor market activities (usually familial). People adhering to these identities consider labor-market success as instrumental to achieving their life goals. In these groups, labor-market success (career) and personal success (self-image) go hand in hand, and individuals spend a long time in the labor market, thus complying with the working time norm. These observations induce one to expect a positive relationship between the importance of the labor market in achieving life goals and the importance attributed to certain job attributes, such as pay, career possibilities, and training opportunities.

However, given the large number of groups to which an individual may belong (according to gender, age, occupation, and affiliation to organizations), a person's social identity is likely to consist of a mixture of identities that, at times, may command inconsistent or conflicting demands or behaviors (Wichardt 2008). It is not the identities 
per se that conflict with each another but the values, beliefs and norms inherent in these identities. The conflict between identities is latent, and it becomes overt when people are forced to “don different hats”(Ashforth and Mael 1989).

For example, not all identities regard labor-market behaviour as important: people adhering to these other identities consider non-work activities (leisure, care, child-rearing) as important for their sense of self. At the same time, these very same individuals may also adhere to identities that stress the instrumentality of labor-market success to their sense of self. These people may be confronted with a difficult choice when engaged in labor-market activities. Some individuals may simply eschew labor-market activities, while others may sacrifice non-labor market activities. Still others may participate in the labor market, possibly on a part-time or temporary basis (Hakim 2000, Riedmann et al. 2006).

Workers who adhere to identities emphasise non-work activities may be subject to pressures while spending time in the labor market (work-to-home or home-to-work conflict). For example, non-work activities play a major role in women's lives (are more important for their identity); yet women may nonetheless work until, typically, childbearing (Babcock and Laschever 2003). Career women, whose self-images are centered on their labor-market success, return to their jobs sooner than do women who centre their self-images around the family (similarly, men characterized by work-oriented self-images may not take a period of leave to assist their spouses in the days following child-birth). In fact, it is no coincidence that the majority of women working on part-time schedules have young children or have returned to the labor market after a spell of non-participation due to child-bearing and child-rearing (Hakim 2000, Riedmann et al. 2006).

Some individuals will therefore experience work and non-work activities as being in conflict with each other, while others will not. The former will feel under pressure, while the latter will feel busy and productive. These different perceptions depend on whether these individuals like what they are doing, and on whether those close to them (their "significant others") think that they are doing the right thing, that they are behaving coherently with their identity (Thompson and Bunderson 2001). It follows that individuals who adhere to an identity that stresses the importance of non-labor market activities may perceive a conflict between the behavior prescribed by other identities to which they subscribe. These individuals apparently fail to integrate the behavioural prescriptions inherent in their identities because these make inconsistent or incoherent claims upon 
them.. This particular kind of conflict may take the form of a 'time crunch' (Fuchs Epstein and Kalleberg 2004, Thompson and Bunderson 2001). ${ }^{2}$

These observations induce one to expect a positive relationship between the failure to integrate rival norms and behaviors arising from the different identities to which individuals adhere and the importance given to job characteristics likely to decrease the extent of the conflict between the inconsistent claims posed by rival identities. For example, the behavioral conflict may concern the time allotted to work and non-work activities, and job attributes that can mitigate the conflict are holidays, flexible working hours, part-time, and good (supportive) relationship with colleagues and managers. ${ }^{3}$

\section{The data and measurement issues}

The data set used consists of 1828 individuals (47\% of them women) representative of the Dutch population (a random sample). The data were collected with structured questionnaires administered electronically. ${ }^{4}$ The questionnaire covered items about work attitudes, desired job attributes, and preference for part-time or full-time employment. The data collected, however, did not contain any information about job title, occupation, industry or firm size. ${ }^{5}$

Here we describe the features of the data that are relevant to the analysis, and broken down by desired number of hours. The interested reader can find a more detailed data description in Van Hooft et al. (2005). About 77\% of the respondents were employed at the moment of the data collection: $62 \%$ had permanent contracts, $9 \%$ were in temporary jobs, and

\footnotetext{
${ }^{2}$ Labor-market behavior will be affected too, as illustrated by the "theory of planned behavior" (Ajzen 2001, Godin et al. 2005, Hagger and Chazisarantis 2005). This theory posits that individuals in general behave according to the importance attributed to job characteristics. However, other important intervening factors norms, attitudes, self-efficacy - may reduce the correlation between stated preferences and observed behavior (Ajzen 2005).

${ }^{3}$ To the extent that identities influence the importance individuals attribute to job characteristics, they have economic value because they may be sources of wage differences across individuals (compensating differentials). Economists acknowledge the importance of heterogeneity in workers' preferences (Gronberg and Reed 1994, Hwang et al. 1992, Hwang et al. 1998, Jolivet and Bonhomme 2008), but the source of this heterogeneity usually is left unexplained (or is attributed to different degrees of risk aversion when hazardous jobs are considered). Moreover, because an identity is a construct that is uncorrelated to individuals' innate abilities or talents, the resulting wage differentials will not be related to workers' heterogeneity in ability. However, because the relative importance of identity vis-à-vis ability in generating wage differentials cannot be assessed with the data at hand, we must leave this issue for future research.

${ }^{4}$ The sample is nevertheless representative because it was recruited by telephone. See www.centre.nl for further details about the recruitment procedure.

${ }^{5}$ The data are not suited to investigating the relation between part-time workers' labor-market attitudes and the reasons inducing workers to opt for part-time work arrangements, or their labor-market experiences (Green and Ferber 2005a, 2005b, 2005c, OECD 2003).
} 
$6 \%$ were self-employed. Of the employed workers, $61 \%$ were in full-time employment (more than 34 hours per week), 30\% had a long part-time job (fewer than 35 hours but working 12 hours or more), and 9\% had a small part-time job (fewer than 12 hours per week). ${ }^{6}$ Only 3.5\% of the respondents in full-time employment would have preferred a part-time job, while the incidence of involuntary part-time was fully $22 \%$.

There was a striking gender difference: $81 \%$ of the individuals preferring part-time employment were women. Only $12 \%$ of the men (either employed or not) had a preference for part-time employment, while about $57 \%$ of the women would have liked a part-time job (the length of the desired part-time job was not specified). The preference for part-time employment was stronger among individuals without paid employment (57\%) than it was among the respondents with a paid job (28\%). However, $68 \%$ of the individuals preferring part-time jobs were, in fact, employed. ${ }^{7}$

We now present the items that will be used later to derive the importance of labor market success and the extent of role conflict broken down by the desired number of hours. We have chosen to break down the data along the desired number of hours dimension on the assumption that they will vary with to the importance of the role played by the labor market in workers' lives and in reaction to the presence of role conflict.

Life goals and the importance attributed to job characteristics show significant differences when contrasted in terms of the desired number of hours. ${ }^{8}$ Table 1 focuses on life goals. It shows the results of the comparison of the importance attached to life goals between individuals preferring full-time and part-time jobs.

Individuals preferring full-time jobs attach more importance to income, status, and to having responsibilities, and less importance to obtain respect, social contacts, leisure time, and a work-family balance than do their colleagues who prefer part-time jobs.

TABLE 1 ABOUT HERE.

\footnotetext{
${ }^{6}$ The classification of part-time jobs adopted appears to have been rather accurate: $6.6 \%$ of all jobs with between 30 and 35 working hours per week are full-time jobs, while $2.7 \%$ of all jobs involving more than 35 working hours per week are, in fact, part-time jobs (Dutch Central Bureau of Statistics, Survey on Employment and Wages).

${ }^{7}$ There is also a gender difference in family roles: $62 \%$ of the respondents reported themselves to be household heads. The incidence of household heads was 86\% (31\%) among men (women); similarly, 32\% of the respondents were spouses, the incidence of spouses was as low (high) as 6\% (61\%) among men (women). ${ }^{8}$ All items were originally coded on a 1 to 5 scale ( 1 not at all important, 5 very important). The items were recoded into dummy variables setting the high scores (4 and 5) equal to 1 and the low scores (1, 2, and 3) to nought because the data set was not large enough to estimate a multivariate ordered probit (with 5 classes). We describe the data thus transformed for the sake of consistency.
} 
The second identity-related aspect considered was the extent to which having a job was perceived to be instrumental in achieving specific life-goals. The average scores on these items, again broken down by desire to work part-time, are shown in Table 2.

\section{TABLE 2 ABOUT HERE}

Having a job is perceived to be more instrumental to the achievement of a satisfactory income, status, and order and regularity in life among individuals who want a full-time job than among individuals wanting to work part-time, who, in turn, consider having a job as more instrumental to achieving a sense of security than do individuals who prefer to work full-time. Interestingly, the importance of feeling secure does not present significant variation along the desired number of working hours dimension. However, having a job is more important for a sense of security among individuals who prefer to work full-time than among those who prefer a part-time job.

Individuals’ identities circumscribe life domains that are relevant for the individual's sense of self. That is, progress in these domains, or the lack thereof, will affect the individual's sense of self and his/her well being. The importance that individuals' identities attribute to labor-market success may be recovered by combining the information contained in Tables 1 and 2. Table 1 identifies life domains that are important for individuals' sense of self, while Table 2 singles out the importance of labor-market success in the relevant life domain. Hence a measure of the importance of labor-market activity for the achievement of life goals (WI index) can be obtained as follows:

$$
W I=\frac{1}{11 * 5} \sum_{i \in A} I T_{i} * I T_{i+13} \quad A:\left\{I T_{1} \cdots I T_{10}, I T_{12}\right\}
$$

where IT denotes the item number (as in the first column of Table 1 - Table 2). The WI index captures the extent to which an individual's identity centers on the labor market: it is a weighted average of life-goals, the weights being the importance of having a job in order to attain the particular life goal. ${ }^{9}$ Identities stressing the importance of labor-market success would result in high scores on the WI index.

We now turn to the importance attached to job attributes, bearing in mind that insofar as identities prescribing a full-time presence in the labor market are likely to emphasise labor-

\footnotetext{
${ }^{9}$ The WI index captures values related to the power and achievement constructs typical of the personal identity theory (Hitlin 2003), but it also includes aspects relative to the expectations implicit in societal roles (identity theory) and in social norms (social identity theory). Hence, it is impossible to ascribe the score on the WI index to a specific identity theory.
} 
market success, and identities prescribing only a limited participation are instead likely to stress the social aspect of labor-market participation, we ought to observe differences in the preferred job characteristics along the preferred working hours dimension that are consistent with the underlying identities. Table 3 presents the average scores attached to various job attributes broken down by desired work schedule (part-time versus full-time). ${ }^{10}$

\section{TABLE 3 ABOUT HERE}

Individuals who prefer full-time jobs tend to regard labor-market participation as an investment: job security, training and career opportunities, the opportunity to work in a challenging and stimulating job, and job security are found to be more important in this group than among individuals preferring part-time work.

On the other hand, good working conditions, good relationships with managers and colleagues, the opportunity to take days off, the firm's location (i.e. commuting time), and the opportunity to work favorable shifts are all items that score higher among workers who would like to work part-time than among individuals who want to work full-time; notice that these differences are irrespective of gender (Russo and Van Hooft 2009). Of course, the presence of childcare provision is particularly important for this group of workers.

Overall, individuals who prefer to work part-time appear less sensitive than their colleagues preferring full-time work to the means that firms generally use to provide incentives. This result matches the low incidence of promotions among part-time workers. ${ }^{11}$

To assess whether the differences in the job characteristics sought are indicative of different attitudes to the labor market, we now analyze differences in individuals’ attitudes toward work and issues of life satisfaction broken down by preferred working time. The results are presented in Table 4.

TABLE 4 ABOUT HERE

\footnotetext{
10 The precise question asked was: "When searching for a (different) job I pay attention to the following aspects" ,then the items in Table 3 were listed. The possible answers were coded on a Likert scale that ranged from "complete agreement" (score 5) to "complete disagreement" (score 1).

${ }^{11}$ Cognitive dissonance theory suggests that the experience of reduced career and training opportunities and workplace frictions (Blau and Ehrenberg 1997, Fuchs Epstein et al. 1999) may cause part-time workers to take a different stance on these issues when they explain to themselves why they have accepted such treatment (Akerlof and Kranton 2005).
} 
Individuals who prefer to work part-time report a lower level of agreement than do workers preferring full-time work. They use statements such as: "work is an important aspect of life”, “work gives meaning to life”, and "work is a source of satisfaction”. This pattern of results has also been found to characterize the difference between part-time and full-time workers in the US (Thorsteinson 2003).

Moreover, on the three items (items 48, 49, and 50) measuring intrinsic motivation (Benabou and Tirole 2003, Deci and Ryan 2002), workers who prefer part-time work score better or no differently from workers who prefer a full-time work schedule. Note that personal interest in a given task is a key motivational element (Deci et al. 1999a).

Because it is still debated whether affective and evaluative dimensions should be included in the conceptualization of group identification (Ashforth and Mael 1989), we collapsed these items into an autonomous index (WA) that captures attitudes and orientations toward work:

$$
W A=\frac{1}{6} \sum_{i \in B} I T_{i} \quad B:\left\{I T_{45}, I T_{46} \cdots I T_{50}\right\}
$$

where IT denotes the Item number. ${ }^{12}$

The importance of the labor-market domain may be eroded when non-work activities are deemed very important. Table 5 shows that this aspect may be particularly significant for individuals who prefer part-time work. When non-work activities are important for the sense of self, they may become barriers to work (they may prevent individuals from spending time on labor-market activities). When this happens, people experience a role conflict: the labor market absorbs too much of their time and leaves them with insufficient time to carry out the prescribed non-work activities satisfactorily.

In fact, workers who prefer to work part-time tend to perceive a job as a source of rigidity and stress more than do individuals who prefer full-time jobs. In addition, labormarket activities appear to crowd out household work and care activities. Finally, individuals who prefer part-time work are more likely to perceive commuting and a lack of childcare as barriers to work than their colleagues preferring full-time jobs. ${ }^{13}$

\footnotetext{
${ }^{12}$ Factor analysis (unreported) shows that the six items load on one factor (two factors have a positive eigenvalue but the first one is about eight times more important than the second one in terms of variance explained). The six items load with similar weights on the first factor.

13 The question asked was as follows "In your opinion, to what extent are the following items an impediment to having a job?”, The answers were recorded on a Likert scale that ranged from "A very large impediment” (score 5) to "Not an impediment at all” (score 1).
} 


\section{TABLE 5 ABOUT HERE}

We built two more indexes informative of individuals' identity along two additional dimensions:

- $\quad$ the degree of conflict between work and non-work activities (CC index);

- the degree of resistance to labor-market activities (WN index).

These are illustrated by equation [3]: ${ }^{14}$

$$
\begin{array}{ll}
C C=\frac{1}{7} \sum_{i \in C} I T_{i} & C:\left\{I T_{51}, I T_{52}, I T_{54} \cdots I T_{56}, I T_{24}, I T_{26}\right\} \\
W N=\frac{1}{5} \sum_{i \in D} I T_{i} & D:\left\{I T_{53}, I T_{57} \cdots I T_{60}\right\}
\end{array}
$$

where IT denotes the item number. The CC index captures the presence of conflicting claims arising from multiple identities. The index was obtained by averaging all the items that signaled the presence of competing claims on an individual's time or the presence of a conflict between work and non-work activities (work in conflict with other activities, friends, leisure, family, or care activities, ${ }^{15}$ or generating work-to-family conflict).

The WN captures resistance to work, independently of the presence of alternative activities to which individuals might be committed: it measures the unattractiveness of workrelated behaviors and the difficulties encountered in performing them.

The four indexes, ${ }^{16}$ broken down by preferred work schedule, are summarized in Table 6, Panel A. ${ }^{17}$

\footnotetext{
${ }^{14}$ To retain all the variability present in the data the indexes were computed before transforming the items into dummy variables. All items used were defined on a 1 to 5 scale; consequently the four indexes are also based on a 1 to 5 scale.

${ }^{15}$ Indeed, childcare services are in short supply especially for children between 0 and 4 years of age (Plantenga and Remery 2009). However, analyses show that women's attitudes toward work and toward the use of formal childcare services are also heavily influenced by their social identity (the norms and values). The development of the identity (norms and values) is likely to take place through socialization: in fact, the greater the use of formal childcare arrangements in the parents' social network, the higher the likelihood that the parents will use childcare arrangements themselves. In addition, the higher the incidence of working women in the mother's social network the higher the likelihood that the mother will be working (Ooms et al. 2007, Portegijs et al. 2006).

${ }^{16}$ The participants had to agree on Likert scales to more than sixty items. As many of these items resembled each other, it is likely that there was a response bias, i.e. the answers to the latter items were artefacts of the answers to the former. In fact, the items were arranged following a blocked-item presentation; that is, the items were presented to all participants in the study in the same order. We acknowledge that response-bias may represent a limitation of our study. However, when it comes to tapping underlying constructs, previous research has generally concluded that randomized item presentation does not lead to conclusions different from or more valid than those from blocked-item presentation (Sparfeldt et al. 2006).

${ }^{17}$ The survey items stemmed from well-established scales that were designed (and validated) to tap the underlying construct (Van Hooft 2004).The reliability indicators (Cronbach's alpha) relative to the four indexes are: 0.66 (WN index), 0.70 (CC index), 0.80 (WA index) and 0.92 (WI index). These are not particularly strong values (except those for the WA and WI indexes, of course). However, the reliability indicator depends on the number of items used. For example, if the number of items used in the CC, WA and WN indexes rose to ten,
} 


\section{TABLE 6 ABOUT HERE}

Individuals who preferred to work on a part-time schedule scored higher on the CC and the WN (work resistance) indexes than did their counterparts who preferred a full-time schedule. Rather interestingly, individuals who prefer part-time do not seem to attribute lower importance to labor-market activities and to hold a attitude towards work different from those of their colleagues preferring full-time work. In fact, the work importance index is positively, albeit weakly, correlated with the role conflict index. Moreover, the work importance (role conflict) index is positively correlated with the work attitude (work resistance) index, while the role conflict index is negatively correlated with the work attitude index. The pattern of correlation indeed suggests that our indexes measure different underlying (latent) factors.

The relationship between the preference to work part-time and preferences for job attributes is intriguing. However, these are aggregated data, and the relationship found may have been spurious. We therefore put our conjectures to the test of a multivariate analysis.

\section{Empirical analysis}

In the empirical analysis we related the importance of labor-market success (driven by identity), attitudes toward work, the experience of conflict and of barriers to work - as captured by the four indexes described above - to the importance attached to seven job attributes: pay level, career opportunities, training opportunities, the possibility of working on a favorable schedule, a good working climate (good relationships with managers and colleagues), opportunity to do interesting tasks, and the desire to work part-time. ${ }^{18}$ All the dependent variables were recoded into dummy variables (taking value 1 in correspondence to the two highest values of the original Likert scale and zero otherwise). The empirical model thus simplified into a multivariate probit model consisting of seven equations. The crossequation error correlation matrix was also estimated. ${ }^{19}$

with a constant inter-item correlation, the corresponding values of the indexes would be $0.77,0.87$, and 0.8 respectively. For the sake of comparison it is interesting to note that the Cronbach's alpha relative to personality traits, in one recent study of the effect of personality traits on earnings using US data, ranged from 0.60 to 0.77 (Mueller and Plug 2006).

${ }^{18}$ The importance attributed to the pay level correlates extremely strongly with the importance attributed to the benefits and to the sense of security. Using an indicator obtained from the three items combined instead of the pay level does not alter the results of our analysis..

${ }^{19}$ The dependent variables are so relevant that we can plausibly assume that, over time, individuals have gathered considerable experience on these matters. The information and labor-market experience thus accumulated would reduce the influence of measurement errors (Bertrand and Mullainathan 2001). 
The results for the whole sample are presented in Table $7{ }^{20}$ the accompanying correlation coefficients are presented in Table 8.

\section{TABLE 7,8 ABOUT HERE}

Predictably, reported difficulties relating to the lack of childcare facilities increase the salience of the opportunity to work on a favorable work schedule and the likelihood of preferring part-time jobs.

Individuals who display a preference for leisure give importance to job attributes that give them enough free time (interest in a favorable working schedule and preference for parttime work), but they also attribute importance to a good work climate.

The importance of work-family balance increases the saliences of pay level, the opportunity to work at favorable times, and the likelihood of preferring part-time work.

We find that a high score on the WI (work importance) index, which typifies identities that emphasize the importance of work-related issues, has a positive effect on the likelihood of finding all job characteristics important (except working on favorable work schedules) and has a negative impact on the preference for part-time work. A high score on the work attitude index (WA), a construct that gauges the effect of intrinsic motivation, tends to increase the salience of the availability of training opportunities and of the opportunity to do interesting and challenging tasks. ${ }^{21}$

High scores on the work resistance index (WN) tend to increase the salience of having a good work climate and of having the opportunity to do an interesting and challenging job.

As to be expected, individuals experiencing role conflict, attributing importance to leisure and to work-family balance, and experiencing problems with the lack of childcare are more likely to attribute importance to a favorable work schedule (and to part-time). The importance of a favorable work schedule increases when labor-market participation tends to conflict with non labor-market activities, while the importance attributed to labor-market success and individuals' attitudes toward work do not seem to matter. Instead, a high score on

\footnotetext{
${ }^{20}$ The explanatory variables included in all models require further description (the full list is given in the data appendix). The number of hours worked is actually an interaction term between being in employment (either permanent, temporary or self employed) and the working hours (full-time, the reference group, part-time or small part-time). Financial situation is the (self-reported) ability to make ends meet (based on a five-point Likert scale).

${ }^{21}$ These items may influence an individual's sense of control over his/her actions (Benabou and Tirole 2003, Deci et al. 1999a, 1999b, Eisenberger et al. 1999).
} 
the work importance (work attitude) index has a negative (positive) impact on the desire to work part-time.

Finally, high scores on the Conflicting Claims index (CC) - which signals that the individual fails to integrate the behavioral norms prescribed by the various social identities s/he holds (adherence to identities that stress the instrumentality of success in non-work activities) - heighten the importance of those attributes (such as the opportunity to work at favorable times and the preference for part-time work) that make it possible to reduce the degree of conflict through the pursuit of the non-work activities prescribed. Moreover, a high score on the CC index is found to increase the salience of a good work climate and career possibilities. $^{22}$

The estimates suggests that women tend to attach less importance to career opportunities and more importance to favorable working times (flexibility) and to a good work climate and that they are more likely than men to prefer part-time work. However, this result may be spurious owing to the residual variation deriving from restricting the effect of exogenous variables to be the same for men and women. In fact, because of the salience of gender in these matters, the models ought to have estimated for men and women separately. The numerosity of the data set was not large enough to accommodate estimation of the model on a sub-sample that would have halved the number of observations.

To assess, albeit imperfectly, the effects of gender, we used interaction terms between gender and the four indexes and the number of hours worked (see Appendix 2).

The introduction of an interaction term between the CC index and the gender dummy highlights a very interesting gender split: while high scores on the CC index lead to high importance being attached to career opportunities for men, the positive effects are undone by a negative coefficient, of roughly the same size, for women. In other words, the CC index reveals the presence of a conflict between work and non-work activities which is resolved in favor of work activities by men (the time investment in career). On the other hand, the CC index is not related to the importance of career among women: that is, some women experiencing difficulties in integrating the behavioral prescription stemming from the identities to which they adhere will be career-oriented women, yet other women will not be

\footnotetext{
${ }^{22}$ To the extent that the likelihood of attributing importance to job characteristics reflects actual job attributes, there may be an issue of reverse causation, especially in the case of the role conflict/importance of career opportunity nexus is concerned. Workers holding jobs that offer career opportunities may be particularly under pressure and hence prone to experience role conflict. This prediction is not borne out by the data, however. The average of the role conflict index for workers who attribute importance to career opportunity (2.85) is very close to (and not statistically different from) the average of the role conflict index in the group of workers who do not attach importance to career opportunities (2.82).
} 
career-oriented. ${ }^{23}$ Similarly, the introduction of the interaction term between gender and the conflicting claims index cancels out the positive effect of the CC index on the desire to work part-time, which is replaced by a strong positive effect of the CC index on the desire to work part-time among women. ${ }^{24}$ That is, women that experience conflicting claims use the option to work part-time to balance market and non-market activities.

The introduction of an interaction term between gender and the importance of the work-home balance increased the likelihood to give importance to the possibility to do interesting and challenging job among men and reduced it among women. We also found a positive effect of the number of working hours on the likelihood of attaching importance to the pay level. However, the interaction of the number of hours with gender shows that, relative to full-time status, part-time status is associated with a lower likelihood of importance being attached to pay level among men but not among women

The pattern of cross-equation correlations found is generally positive, the only exception being the error of the equation for the desire to work part-time: unobserved factors increasing the desire to work part-time tend to decrease the importance attached to career and training opportunities.

To check the robustness of the results to the issue of non-participation we estimated the same model for employed workers only. The only parameters significantly affected were those regarding the desire to work part-time. Among employed workers, the effect of gender, of the importance of work-home balance, and of the work attitudes (WA) and work importance (WI) indexes on the desire to work part-time disappeared. By contrast, the effect of a lack of childcare facilities was reinforced. Also the cross-equation error correlation matrix was broadly unchanged. ${ }^{25}$

\section{Conclusions}

\footnotetext{
${ }^{23}$ Interaction terms in non-linear models are difficult to interpret (Ai and Norton 2003). Our interpretation of the effect is supported by the fact that the marginal effect of the CC index on the importance of career is small (negative) and is significant for one third of the observations only (for the sake of simplicity the cross-equation correlation matrix was constrained to be equal to the identity matrix).

${ }^{24}$ The marginal effect, although always positive throughout the range of the predicted probability, is almost never significant.

${ }^{25}$ All these additional results are not shown in the paper for lack of space,. However, they can be obtained form the first author upon request.
} 
The paper has empirically investigated the link between identities and the importance attributed to job characteristics, which, in its turn, is one of the key determinants of labormarket behavior (Ajzen 2005).

The three main findings from the analysis can be summarized as follows: first, identities can be fruitfully integrated into economic analysis. Second, identities are not 'black and white' situations, because individuals can (and generally do) adhere to multiple identities, and integrating the different behavioral norms of those identities may generate conflict. This conflict, in turn, affects the decisions and preferences of economic agents in significant ways. Third, there is a gender split in the way identities (and conflict) affect the preferences of economic agents.

We now elaborate these results further. First, individuals adhere to identities, and our analysis has shown that those identities can be readily integrated into an empirical economic analysis.

We have used four indexes to capture different aspects with a bearing on the importance of the labor market for the identity to which individuals adhere. The work importance index measured the importance of labor-market success in achievement of life goals. The work attitude index measured the attitude to the labor market. The Conflicting Claims index measured the degree of (perceived) conflict between work and non-work activities arising from failure to integrate the behavioral norms governing the (two) domains emanating from the multiple identities to which individuals adhere. Finally, the work resistance index measured, in negative, the importance of perceived barriers to labor-market participation.

The results show that individuals who regard labor-market success as instrumental to achievement of their life goals (high scores on the WI index) attach importance to job characteristics such as pay level and career and training opportunities.

The second result, and the novel aspect of the analysis, is that in reality individuals adhere to several identities. These may make inconsistent claims or demands on individuals, who in turn will experience a time crunch and discomfort. However, flexibility can attenuate the conflict. Consistently with this intuition, individuals characterized by a high score on the Conflicting Claims index are likely to attach importance to the possibility of working on a convenient time schedule and in a good and supportive work environment (represented by their relationships with managers and colleagues). Moreover, they are also more likely to want a part-time job than are individuals who do not experience role conflict. 
Finally, we have also found interesting gender differences. As to be expected, we found that men appear to resolve the conflict between career and non-work activities in favor of the former. However, and this is more interesting because it is rather counter-intuitive, for women the presence of role conflict is not associated with the importance of a career. In fact, women characterized by high scores on the Conflicting Claims index (CC) are not more likely to attach importance to career opportunities than are otherwise equal women characterized by a low scores on the conflicting claims index..

\section{Acknowledgements}

The authors are grateful to Mary Gregory, Wolter Hassink, and Ioannis Theodossiou for helpful comments. The paper has also benefited from discussion with participants at seminars at the Utrecht School of Economics, Trieste University, Modena University and at the Lower conference "What works for women" in Volos (Greece, 2006). Comments by two anonymous referees have greatly improved the focus of the paper.The usual disclaimer applies.

\section{References}

Ai, C. and Norton, E. C. (2003) "Interaction terms in logit and probit models" Economic Letters, 80, 123 - 129.

Ajzen, I. (2001) "Nature and operation of attitudes" Annual Review of Psychology, 52, 27 58.

Ajzen, I. (2005) Attitudes, personality and behavior, Maidenhead, Open University Press. Akerlof, G. A. and Kranton, R. E. (2000) "Economics and Identity" The Quarterly Journal of Economics, 65, 715 - 753.

Akerlof, G. A. and Kranton, R. E. (2005) "Identity and the economics of organizations" Journal of Economic Perspectives, 19, 9 - 32.

Ashforth, B. E. and Mael, F. (1989) "Social identity theory and the organization" The Academy of Management Journal, 14, 20 - 39.

Babcock, L. and Laschever, S. (2003) Women don't ask: negotiation and the gender divide, Princeton, Princeton University Press.

Benabou, R. and Tirole, J. (2003) "Intrinsic and extrinsic motivation" Review of Economic Studies, 70, 489 - 520.

Bertrand, M. and Mullainathan, S. (2001) "Do people mean what they say? Implications for subjective survey data" American Economic Review, 91, 67 - 72.

Blau, F. D. and Ehrenberg, R. G. (1997) Gender and family issues in the workplace, New York, Russel Sage Foundation.

Booth, A. L. and van Ours, J. C. (2008) "Hours of work and gender identity: does part-time work make the family happier?" Economica, forthcoming,

Burke, P. J. (2004) "Identities and social structure: the 2003 Cooley-Mead award address" Social Psychology Quarterly, 67, 5 - 15.

Deci, E. L., Koestner, R. and Ryan, R. M. (1999a) "A meta-analytical review of experiments examining the effects of extrinsic rewards on intrinsic motivation" Psychological Bulletin, 125, 627 - 668. 
Deci, E. L., Koestner, R. and Ryan, R. M. (1999b) "The undermining effect is a reality after all - extrinsic rewards, task interest, and self determination: reply to Esienberger, Pierce, and Cameron (1999) and Lepper, Henderlong, and Gingras (1999)" Psychological Bulletin, 125, $692-700$.

Deci, E. L. and Ryan, R. M. (2002) Handbook of Self-Determination research, Rochester (NY), The University of Rochester Press.

Eisenberger, R., Pierce, D. W. and Cameron, J. (1999) "Effects of rewards on intrinsic motivation - negative, neutral, and positive: a comment on Deci, Koestner and Ryan (1999)" Psychological Bulletin, 125, 677-691.

Fuchs Epstein, C., Seron, C., Oglensky, B. and Sauté, R. (1999) The part-time paradox: time norms, professional life, family and gender, New York, Routledge.

Fuchs Epstein, C. and Kalleberg, A. L. (2004) Fighting for time: shifting boundaries of work and social life, New York, Russell Sage Foundation.

Godin, G., Conner, M. and Sheeran, P. (2005) "Bridging the intention-behaviour 'gap': the role of moral norm" British Journal of Social Psychology, 44, 497-512.

Green, C. A. and Ferber, M. A. (2005a) "The long-run effect of part-time work" Journal of Labor Research, 26, 56 - 85.

Green, C. A. and Ferber, M. A. (2005c) "Do detailed work histories help to explain gender and race/ethnic wage differentials?" Review of Social Economy, 63, 56 - 85.

Gronberg, T. J. and Reed, R. W. (1994) "Estimating workers' marginal willingness to pay for job attributes using duration data" The Journal of Human Resources, 29, 911 - 931.

Hagger, M. S. and Chazisarantis, N. L. D. (2005) "First- and higher-order models of attitudes, normative influence, and perceived behavioural control in the theory of planned behaviour"

British Journal of Social Psychology, 44, 513-535.

Hakim, C. (2000) Work-lifestyle choices in the 21st century: preference theory, Oxford, Oxford University Press.

Halsam, A. S. (2004) Psychology in organizations: the social identity approach, London, Sage.

Hitlin, S. (2003) "Values as the core of personal identity: drawing links between two theories of self" Social Psychology Quarterly, 66, 118 - 137.

Hwang, H.-s., Reed, R. W. and Hubbard, C. (1992) "Compensating wage differentials and unobserved productivity" The journal of Political Economy, 100, 835 - 858.

Hwang, H.-s., Mortensen, D. T. and Reed, R. W. (1998) "Hedonic wages and labor market search" Journal of Labor Economics, 16, 815 - 847.

Jolivet, G. and Bonhomme, S. (2008) "The pervasive absence of compensating differentials", Free University Amsterdam, Mimeo.

Landers, R. M., Rebitzer, J. B. and Taylor, L. J. (1996) "Rat race redux: adverse selection in the determination of work hours in law firms" The American Economic Review, 86, 329 - 348.

Mueller, G. and Plug, E. (2006) "Estimating the effect of personality on male and female earnings" Industrial and Labor Relations Review, 60, 3 - 22.

Nisbett, R. and Ross, L. (1991) The person and the situation, New York, McGraw-Hill. OECD (2003) Employment Outlook, Paris, OECD.

Ooms, I., Eggink, E. and van Gameren, E. (2007) Moeders, werk en kinderopvang in model. Analyse van arbeidsparticipatie- en kinderopvangbeslissingen van moeders met jonge kinderen, Den Haag, Sociaal en Cultureel Planbureau. Plantenga, J. and Remery, C. (2009) The provision of childcare services. A comparative review of 30 European countries, Bruxelles, European Commission Directorate-General for Employment, Social Affairs and Equal opportunities.

Portegijs, W., Cloïn, M., Ooms, I. and Eggink, E. (2006) Hoe het werkt met kinderen: moeders over kinderopvang en werk, Den haag, Sociaal en Cultureel Planbureau. 
Riedmann, A., Bielenski, H., Szczurowska, T. and Wagner, A. (2006) Working time and work-life balance in European companies, Dublin, European Foundation for the Improvement of the Working Conditions.

Russo, G. and Van Hooft, E. A. J. (2009) "Workers' lifestyle choices, working time and job attributes" in T. Addabbo and G. Solinas Non standard employment and quality of work, Heidelberg, Springer Verlag. Sparfeldt, J. R., Schilling, S. R., Rost, D. H. and Thiel, A. (2006) "Blocked Versus Randomized Format of Questionnaires: A Confirmatory Multigroup Analysis" Educational and Psychological Measurement, 66, 961 - 973.

Stets, J. E. and Burke, P. J. (2000) "Identity theory and social identity theory" Social Psychology Quarterly, 63, 224 - 237.

Thompson, J. A. and Bunderson, S. J. (2001) "Work-Nonwork conflict and the

phenomenology of time:beyond the balance metaphor" Work and Occupations, 28, 17 - 39. Thorsteinson, T. J. (2003) "Job attitudes of part-time vs. full-time workers: a meta analytic review" Journal of Occupational and Organizational Psychology, 76, 151-177.

Van Hooft, E. A. J. (2004) Job seeking as planned behavior: in search of group differences, Enschede, Febodruk BV.

Van Hooft, E. A. J., Born, M. P., Taris, T. W. and van der Flier, H. (2005) "Predictors and outcomes of job search behavior: the moderating effect of gender and family situation" Journal of Vocational Behavior, 67, 133 - 152.

Wichardt, P. C. (2008) "Identity and why we cooperate with those we do" Journal of Economic Psychology, 29, 127 - 139. 
Table 1: Life goals (1 important or very important; 0 not important or indifferent) by preferred number of hours (**: significant at $5 \%$, *:significant at $10 \%)$

item

1 Having Enough Money

2 Feeling that One is Useful

3 Social Contacts

4 Respect

5 Sense of Security

6 Having Order and Regularity in Life

7 Variation

8 Having Tasks that Match Knowledge and Skills

9 Being Able to Grow and Develop

10 Status

11 Work-Life Balance

12 Having Responsibilities

13 Having Enough Leisure Time

Number of cases

\section{Full-time Part-time}

0.43

0.71

0.70

0.68

0.66

0.45

0.61

0.67

0.66

0.14

0.64

0.52

0.69

1828
0.34 **

0.73

$0.76^{\text {** }}$

$0.73^{\text {** }}$

0.67

0.42

0.60

0.68

0.64

$0.08^{\text {** }}$

0.69 **

0.47 *

0.76 **

386
T-test Score

2.96

$-0.58$

$-2.21$

$-2.00$

$-0.50$

1.12

0.50

$-0.46$

0.85

3.35

$-2.06$

1.93

$-2.59$ 
Table 2: The importance of having a job to attain life goals (1 important or very important; 0 not important or indifferent) by preferred number of hours $(* *$ : significant at $5 \%$, *:significant at $10 \%)$

item

Full-time Part-time T-test Score

14 Having Enough Money

15 Feeling that One is Useful

Thest Score

16 Social Contacts

17 Respect

18 Sense of Security

19 Having Order and Regularity in Life

20 Variation

21 Having Tasks that Match Knowledge and Skills

22 Being Able to Grow and Develop

23 Status

24 Work-Life Balance

25 Having Responsibilities

26 Having Enough Leisure Time

$\begin{array}{llr}0.63 & 0.58^{\star \star} & 2.06 \\ 0.57 & 0.53 & 1.37 \\ 0.52 & 0.51 & 0.42 \\ 0.56 & 0.57 & -0.20 \\ 0.59 & 0.51^{\star \star} & 2.63 \\ 0.49 & 0.42^{\star *} & 2.43 \\ 0.46 & 0.45 & 0.27 \\ 0.61 & 0.58 & 0.88 \\ 0.58 & 0.54 & 1.32 \\ 0.25 & 0.20^{\star *} & 2.08 \\ 0.30 & 0.28 & 1.01 \\ 0.51 & 0.47 & 1.56 \\ 0.23 & 0.20 & 1.26 \\ & & \\ 1442 & 386 & \end{array}$

Number of cases

1828 
Table 3: Importance of job attributes (1 important or very important; 0 not important or indifferent) by preferred number of hours (**: significant at $5 \%, *$ :significant at $10 \%)$

item

27 Pay Level

28 Benefits

29 Career Possibilities

30 Job Security

31 Working Conditions

32 Favourable Working Time

33 Firm's Location

34 Holidays (and days off)

35 Possibility to Work with Colleagues

36 Firm's Reputation

37 Training Provision

\section{Full-time Part-time}

0.82

0.64

0.73

0.84

0.67

0.64

0.69

0.62

0.62

0.59

0.82

0.38

0.26

0.19

0.21

0.83

0.74

43 Opportunity to Use Own Skills and Abilities

44 Good Relationships With Colleagues and Managers

Number of cases
T-test Score

$\begin{array}{lr}0.77 & 1.10 \\ 0.80 & 0.68 \\ 0.49^{* *} & 5.59 \\ 0.66^{* *} & 2.67 \\ 0.88^{* *} & -2.13 \\ 0.87^{* *} & -7.50 \\ 0.73^{* *} & -3.49 \\ 0.79^{* *} & -3.87 \\ 0.63 & -0.15 \\ 0.56^{*} & 1.89 \\ 0.52^{* *} & 2.76 \\ 0.75^{* *} & 3.16 \\ 0.40 & -0.50 \\ 0.26 & -0.07 \\ 0.33^{* *} & -5.60 \\ 0.23 & -0.62 \\ 0.83 & -0.13 \\ 0.81^{* *} & -2.51\end{array}$

386 
Table 4: Attitudes toward work (1 important or very important; 0 not important or indifferent) by preferred number of hours (**: significant at $5 \%$, *:significant at $10 \%)$

\section{Work}

attitude

item

45 Work is an important part of life

46 Work is a source of satisfaction in one's life

47 Work gives a meaning to one's life

48 If I had enough money, I would still work

49 I enjoy talking about work with others

50 Work means more to me than just money

Number of cases
Full-time Part-time

T-test Score

$\begin{array}{lll}0.70 & 0.65^{*} & 1.78 \\ 0.62 & 0.51^{\star *} & 4.00 \\ 0.48 & 0.37^{\star *} & 3.96 \\ 0.52 & 0.55 & -1.25 \\ 0.52 & 0.53 & -0.48 \\ 0.69 & 0.74 * & -1.74\end{array}$

1828

386 
Table 5: Importance of work-related problems (1 important or very important; 0 not important or indifferent) by preferred number of hours (**: significant at $5 \%$, *:significant at $10 \%$ )

\section{item}

51 Too little time for care

52 Day too tightly organized

53 Not enough increases in income (relative to no job)

54 Too little time for friends

55 Too little time for household work

56 Loss of one's independence

57 Too repetitive

58 Having to spend time with people you might not like

59 Too much pressure and stress

60 Having to obey the orders of others

61 Lack of childcare

62 Transportation (commuting)

63 Dutch language

64 Discrimination

65 Having to do tasks below one's level

Number of cases
Full-time Part-time

T-test Score

$\begin{array}{llr}0.24 & 0.37^{\star *} & -4.96 \\ 0.17 & 0.25^{\star *} & -3.48 \\ 0.30 & 0.28 & 0.58 \\ 0.28 & 0.31 & -0.93 \\ 0.22 & 0.28^{\star *} & -2.69 \\ 0.25 & 0.28 & -1.05 \\ 0.26 & 0.24 & 0.98 \\ 0.17 & 0.13^{*} & 1.85 \\ 0.17 & 0.22^{\star *} & -2.54 \\ 0.08 & 0.09 & -0.51 \\ 0.07 & 0.18^{* \star} & -6.51 \\ 0.07 & 0.11^{* *} & -2.68 \\ 0.01 & 0.00 & 0.86 \\ 0.04 & 0.03 & 1.10 \\ 0.17 & 0.15 & 1.17\end{array}$

1828
1442

386 
Table 6: Work attitude, work importance, work resistance, and time-constraint indexes ( 1 minimum level to 5 maximum level) by preferred number of hours (**: significant at $5 \%, *$ :significant at $10 \%$ )

A

WI: Work importance WN: Work resistance CC: Conflicting claims WA: Work attitude Number of cases

B

$\begin{array}{lcccc} & \text { WI } & \text { WN } & \text { CC } & \text { WA } \\ \text { WI: Work importance } & 1 & 0.01 & 0.09^{\star \star} & 0.32^{\star \star} \\ \text { WN: Work resistance } & & 1 & 0.47^{\star \star} & -0.22^{\star \star} \\ \text { CC: } \text { Conflicting claims } & & & 1 & -0.20^{\star \star} \\ \text { WA: Work attitude } & & & & 1\end{array}$

$\begin{array}{rrr}\text { Full-time } & \text { Part-time } & \text { T-test } \\ 2.62 & 2.60 & 0.21 \\ 2.43 & 2.72^{\star *} & -3.41 \\ 2.73 & 2.92^{\star *} & -2.52 \\ 3.48 & 3.42 & 1.57 \\ 1442 & 386 & \end{array}$


Table 7: Multivariate probit estimates, the whole sample (*: significant at $10 \%$, **: significant at 5\%)

$\begin{array}{lccccccc} & \begin{array}{c}\text { Pay } \\ \text { level }\end{array} & \begin{array}{c}\text { Career } \\ \text { opportunities }\end{array} & \begin{array}{c}\text { Training } \\ \text { opportunities }\end{array} & \begin{array}{c}\text { Favorable } \\ \text { work } \\ \text { schedule }\end{array} & \begin{array}{c}\text { Good } \\ \text { work } \\ \text { climate }\end{array} & \begin{array}{c}\text { Interesting } \\ \text { \& }\end{array} & \begin{array}{c}\text { Wants } \\ \text { challenging }\end{array} \\ \text { part-time }\end{array}$




\begin{tabular}{|c|c|c|c|c|c|c|c|}
\hline small part-time & $\begin{array}{l}-0.39 \\
(0.16) \text { ** }\end{array}$ & $\begin{array}{l}-0.22 \\
(0.15)^{*}\end{array}$ & $\begin{array}{r}-0.08 \\
(0.15)\end{array}$ & $\begin{array}{c}0.47 \\
(0.16) \text { ** }\end{array}$ & $\begin{array}{c}-0.11 \\
(0.16)\end{array}$ & $\begin{array}{l}-0.50 \\
(0.18) \text { ** }\end{array}$ & $\begin{array}{c}1.47 \\
(0.19)^{\text {** }}\end{array}$ \\
\hline \multicolumn{8}{|l|}{ Tenure } \\
\hline 1 - 2 years & $\begin{array}{r}0.02 \\
(0.14)\end{array}$ & $\begin{array}{r}0.10 \\
(0.13)\end{array}$ & $\begin{array}{r}0.01 \\
(0.12)\end{array}$ & $\begin{array}{c}-0.12 \\
(0.13)\end{array}$ & $\begin{array}{c}-0.10 \\
(0.14)\end{array}$ & $\begin{array}{r}-0.11 \\
(0.15)\end{array}$ & $\begin{array}{r}0.11 \\
(0.17)\end{array}$ \\
\hline 3 to 5 years & $\begin{array}{r}0.05 \\
(0.15)\end{array}$ & $\begin{array}{r}-0.15 \\
(0.13)\end{array}$ & $\begin{array}{r}-0.12 \\
(0.13)\end{array}$ & $\begin{array}{c}-0.14 \\
(0.14)\end{array}$ & $\begin{array}{c}-0.11 \\
(0.14)\end{array}$ & $\begin{array}{r}0.01 \\
(0.17)\end{array}$ & $\begin{array}{r}0.22 \\
(0.17)\end{array}$ \\
\hline 6 to 10 years & $\begin{array}{r}0.08 \\
(0.13)\end{array}$ & $\begin{array}{r}0.05 \\
(0.11)\end{array}$ & $\begin{array}{r}0.04 \\
(0.11)\end{array}$ & $\begin{array}{c}-0.18 \\
(0.12) *\end{array}$ & $\begin{array}{r}0.02 \\
(0.12)\end{array}$ & $\begin{array}{r}-0.01 \\
(0.16)\end{array}$ & $\begin{array}{c}0.27 \\
(0.15)^{*}\end{array}$ \\
\hline$>10$ years & $\begin{array}{r}-0.01 \\
(0.13)\end{array}$ & $\begin{array}{l}-0.20 \\
(0.12)^{*}\end{array}$ & $\begin{array}{r}-0.13 \\
(0.12)\end{array}$ & $\begin{array}{l}-0.33 \\
(0.12)^{\star *}\end{array}$ & $\begin{array}{l}-0.23 \\
(0.13)^{*}\end{array}$ & $\begin{array}{c}-0.16 \\
(0.16)\end{array}$ & $\begin{array}{r}0.21 \\
(0.17)\end{array}$ \\
\hline \multicolumn{8}{|l|}{ Education } \\
\hline Primary & $\begin{array}{r}0.07 \\
(0.10)\end{array}$ & $\begin{array}{c}-0.06 \\
(0.09)\end{array}$ & $\begin{array}{r}-0.15 \\
(0.09)\end{array}$ & $\begin{array}{c}0.22 \\
(0.10)\end{array}$ & $\begin{array}{r}0.07 \\
(0.09)\end{array}$ & $\begin{array}{l}-0.21 \\
(0.10)^{* *}\end{array}$ & $\begin{array}{r}0.04 \\
(0.11)\end{array}$ \\
\hline university \& hbo & $\begin{array}{r}0.01 \\
(0.08)\end{array}$ & $\begin{array}{r}0.08 \\
(0.08)\end{array}$ & $\begin{array}{r}0.12 \\
(0.07)\end{array}$ & $\begin{array}{r}-0.03 \\
(0.08)\end{array}$ & $\begin{array}{r}0.09 \\
(0.08)\end{array}$ & $\begin{array}{c}0.24 \\
(0.10)^{\star \star}\end{array}$ & $\begin{array}{r}0.04 \\
(0.09)\end{array}$ \\
\hline \multicolumn{8}{|c|}{ Workers Characterisitics } \\
\hline Age & $\begin{array}{l}-0.05^{*} \\
(0.03)\end{array}$ & $\begin{array}{l}-0.07 \\
(0.03)^{* *}\end{array}$ & $\begin{array}{r}-0.03 \\
(0.03)\end{array}$ & $\begin{array}{r}-0.01 \\
(0.03)\end{array}$ & $\begin{array}{r}0.02 \\
(0.03)\end{array}$ & $\begin{array}{r}-0.03 \\
(0.03)\end{array}$ & $\begin{array}{c}0.09 \\
(0.03)^{\star \star}\end{array}$ \\
\hline age squared & $\begin{array}{r}0.00 \\
(0.00)\end{array}$ & $\begin{array}{c}0.00 \\
(0.00)^{\star *}\end{array}$ & $\begin{array}{r}0.00 \\
(0.00)\end{array}$ & $\begin{array}{r}0.00 \\
(0.00)\end{array}$ & $\begin{array}{r}-0.00 \\
(0.00)\end{array}$ & $\begin{array}{r}0.00 \\
(0.00)\end{array}$ & $\begin{array}{l}-0.00 \\
(0.00)^{\star \star}\end{array}$ \\
\hline total unemployment & $\begin{array}{l}-0.17 \\
(0.10)^{*}\end{array}$ & $\begin{array}{r}0.01 \\
(0.10)\end{array}$ & $\begin{array}{r}0.01 \\
(0.10)\end{array}$ & $\begin{array}{r}-0.00 \\
(0.11)\end{array}$ & $\begin{array}{r}0.03 \\
(0.10)\end{array}$ & $\begin{array}{r}0.01 \\
(0.12)\end{array}$ & $\begin{array}{r}0.15 \\
(0.12)\end{array}$ \\
\hline Income & $\begin{array}{r}0.01 \\
(0.00)\end{array}$ & $\begin{array}{r}-0.01 \\
(0.01)\end{array}$ & $\begin{array}{r}-0.00 \\
(0.01)\end{array}$ & $\begin{array}{r}0.00 \\
(0.01)\end{array}$ & $\begin{array}{r}-0.00 \\
(0.00)\end{array}$ & $\begin{array}{r}0.00 \\
(0.00)\end{array}$ & $\begin{array}{l}-0.00 \\
(0.01)\end{array}$ \\
\hline income squared & $\begin{array}{r}-0.01 \\
(0.01)\end{array}$ & $\begin{array}{c}0.10 \\
(0.06)^{*}\end{array}$ & $\begin{array}{r}0.04 \\
(0.05)\end{array}$ & $\begin{array}{r}0.02 \\
(0.05)\end{array}$ & $\begin{array}{r}0.00 \\
(0.01)\end{array}$ & $\begin{array}{r}-0.01 \\
(0.01)\end{array}$ & $\begin{array}{r}0.00 \\
(0.01)\end{array}$ \\
\hline \multicolumn{8}{|c|}{ Labor Market Experience } \\
\hline 1 - 2 years & $\begin{array}{c}-0.32 \\
(0.18)^{*}\end{array}$ & $\begin{array}{c}-0.18 \\
(0.18)\end{array}$ & $\begin{array}{r}0.14 \\
(0.17)\end{array}$ & $\begin{array}{r}-0.12 \\
(0.19)\end{array}$ & $\begin{array}{r}-0.11 \\
(0.19)\end{array}$ & $\begin{array}{c}-0.08 \\
(0.20)\end{array}$ & $\begin{array}{r}0.00 \\
(0.21)\end{array}$ \\
\hline 2 to 5 years & $\begin{array}{l}-0.30 \\
(0.15) \text { ** }\end{array}$ & $\begin{array}{r}0.02 \\
(0.15)\end{array}$ & $\begin{array}{r}-0.03 \\
(0.14)\end{array}$ & $\begin{array}{r}0.01 \\
(0.16)\end{array}$ & $\begin{array}{r}0.15 \\
(0.16)\end{array}$ & $\begin{array}{c}-0.04 \\
(0.18)\end{array}$ & $\begin{array}{l}-0.52 \\
(0.17)^{\star \star}\end{array}$ \\
\hline 5 to 10 years & -0.19 & -0.10 & 0.08 & 0.12 & 0.01 & 0.01 & -0.31 \\
\hline
\end{tabular}




\begin{tabular}{|c|c|c|c|c|c|c|c|}
\hline & $(0.13)$ & $(0.13)$ & $(0.12)$ & $(0.14)$ & $(0.13)$ & $(0.16)$ & $(0.15)^{\star \star}$ \\
\hline \multirow{2}{*}{$>10$ years } & -0.04 & 0.04 & -0.01 & 0.07 & 0.09 & -0.10 & -0.06 \\
\hline & $(0.11)$ & $(0.10)$ & $(0.10)$ & $(0.11)$ & $(0.10)$ & $(0.12)$ & $(0.12)$ \\
\hline \multicolumn{8}{|c|}{ Household Characteristics } \\
\hline \multirow[t]{2}{*}{ Head } & -0.11 & 0.15 & -0.15 & 0.26 & -0.00 & 0.33 & 0.07 \\
\hline & $(0.18)$ & $(0.15)$ & $(0.17)$ & $(0.17)$ & $(0.16)$ & $(0.20)$ & $(0.18)$ \\
\hline \multirow[t]{2}{*}{ Other } & -0.25 & -0.24 & -0.00 & -0.31 & 0.03 & -0.10 & -0.09 \\
\hline & $(0.23)$ & $(0.22)$ & $(0.21)$ & $(0.22)$ & $(0.23)$ & $(0.27)$ & $(0.26)$ \\
\hline \multirow[t]{2}{*}{ spouse present } & 0.04 & 0.04 & -0.04 & 0.19 & -0.09 & -0.08 & 0.21 \\
\hline & $(0.12)$ & $(0.11)$ & $(0.11)$ & $(0.11)$ & $(0.11)$ & $(0.14)$ & $(0.15)$ \\
\hline \multirow[t]{2}{*}{ breadwinner } & 0.23 & -0.07 & 0.22 & -0.17 & -0.06 & -0.39 & -0.11 \\
\hline & $(0.18)$ & $(0.15)$ & $(0.17)$ & $(0.16)$ & $(0.17)$ & $(0.19)^{*}$ & $(0.18)$ \\
\hline \multirow[t]{2}{*}{1 child } & 0.08 & -0.06 & -0.28 & 0.04 & -0.06 & -0.01 & -0.07 \\
\hline & $(0.12)$ & $(0.11)$ & $(0.11)^{\star}$ & $(0.12)$ & (0.11) & $(0.13)$ & $(0.14)$ \\
\hline \multirow[t]{2}{*}{2 children } & 0.23 & 0.03 & -0.15 & 0.25 & -0.03 & 0.11 & 0.19 \\
\hline & $(0.11)^{\star \star}$ & $(0.10)$ & $(0.10)$ & $(0.11)^{\star \star \star}$ & $(0.11)$ & $(0.12)$ & $(0.12)^{*}$ \\
\hline \multirow[t]{2}{*}{3 children } & -0.06 & 0.03 & -0.12 & -0.13 & -0.10 & -0.10 & 0.12 \\
\hline & (0.14) & $(0.14)$ & $(0.13)$ & $(0.14)$ & $(0.14)$ & $(0.16)$ & $(0.16)$ \\
\hline \multirow[t]{2}{*}{$>3$ children } & -0.27 & -0.34 & -0.47 & 0.27 & -0.09 & -0.24 & 0.23 \\
\hline & $(0.20)$ & $(0.21)^{*}$ & $(0.19)^{\star}$ & $(0.23)$ & $(0.22)$ & $(0.21)$ & $(0.23)$ \\
\hline \multirow[t]{2}{*}{ city type } & -0.02 & 0.02 & -0.02 & -0.10 & -0.10 & -0.00 & -0.14 \\
\hline & (0.08) & $(0.07)$ & $(0.07)$ & $(0.08)$ & $(0.07)$ & $(0.09)$ & $(0.09)^{*}$ \\
\hline \multirow[t]{2}{*}{ financial situation } & 0.22 & 0.22 & 0.14 & 0.13 & 0.29 & 0.20 & 0.00 \\
\hline & $(0.08)^{\star \star}$ & $(0.08)^{\star \star}$ & $(0.07)$ & $(0.08)$ & $(0.08)^{\star *}$ & $(0.09)^{\star \star \star}$ & $(0.09)$ \\
\hline $\begin{array}{l}\text { Provinces } \\
\text { (11 dummies) }\end{array}$ & YES & YES & & YES & YES & YES & YES \\
\hline \multirow[t]{2}{*}{ Constant } & 1.19 & 0.57 & -1.00 & -0.64 & -1.32 & -0.40 & -5.21 \\
\hline & $(0.71)^{\star \star}$ & (0.69) & $(0.70)$ & $(0.74)$ & $(0.73)^{*}$ & $(0.86)$ & $(0.84)^{\star \star}$ \\
\hline \multicolumn{2}{|l|}{ observations } & & & 1828 & & & \\
\hline \multicolumn{2}{|l|}{ Restricted } & & & -6172 & & & \\
\hline \multicolumn{2}{|l|}{ full model } & & & -5585 & & & \\
\hline \multicolumn{2}{|c|}{ Likelihood ratio test: chi2 } & & & 1174 ** & & & \\
\hline
\end{tabular}


The reference group of the variables is given in parentheses: Employment Status (voluntary full-time), Labor-Market Position (permanent job), Total Unemployment (shorter than 1 year), Educational Level (medium), Gender (male)), Tenure (1 year or less), Position in the Household (not married), Spouse in the Household (no spouse in the

household), breadwinner (not bread winner), Province (Limburg), work experience (1 year or less), number of children (no children), city type (does not want to live in city). 
Table 8: Multivariate probit estimates: the correlation matrix (the whole sample 1828 cases, all controls included, *: significant at $10 \%$, **: significant at 5\%)

\begin{tabular}{|c|c|c|c|c|c|c|c|}
\hline & $\begin{array}{l}\text { Pay } \\
\text { level }\end{array}$ & $\begin{array}{c}\text { Career } \\
\text { opportunities }\end{array}$ & $\begin{array}{l}\text { Training } \\
\text { opportunities }\end{array}$ & $\begin{array}{c}\text { Favorable } \\
\text { working } \\
\text { hours }\end{array}$ & $\begin{array}{c}\text { good } \\
\text { work } \\
\text { climate }\end{array}$ & $\begin{array}{c}\text { Interesting } \\
\& \\
\text { challenging }\end{array}$ & $\begin{array}{c}\text { Wants } \\
\text { part-time }\end{array}$ \\
\hline Pay level & 1 & 0.55 & 0.34 & 0.45 & 0.36 & 0.52 & $\begin{array}{r}0 \\
(005)\end{array}$ \\
\hline Career opportunities & & $\begin{array}{c}(0.03)^{\star \star} \\
1\end{array}$ & $\begin{array}{c}(0.04)^{* *} \\
0.58 \\
(0.03)^{\star *}\end{array}$ & $\begin{array}{c}(0.04)^{* *} \\
0.32 \\
(0.04)^{* *}\end{array}$ & $\begin{array}{c}(0.04)^{* *} \\
0.29 \\
(0.04)^{* *}\end{array}$ & $\begin{array}{c}(0.04)^{* *} \\
0.57 \\
(0.04)^{* *}\end{array}$ & $\begin{array}{l}(0.05) \\
-0.11 \\
(0.05)^{* *}\end{array}$ \\
\hline Training opportunities & & & 1 & $\begin{array}{c}0.19 \\
(0.04)^{\star *}\end{array}$ & $\begin{array}{c}0.27 \\
(0.04)^{* *}\end{array}$ & $\begin{array}{c}0.79 \\
(0.03)^{* *}\end{array}$ & $\begin{array}{c}-0.11 \\
(0.05)^{\star \star}\end{array}$ \\
\hline Favorable working hours & & & & 1 & $\begin{array}{c}0.38 \\
(0.04)^{* *}\end{array}$ & $\begin{array}{c}0.47 \\
(0.05)^{\text {** }}\end{array}$ & $\begin{array}{c}0.15 \\
(0.05)^{\star *}\end{array}$ \\
\hline Good work climate & & & & & 1 & $\begin{array}{c}0.63 \\
(0.04)^{* *}\end{array}$ & $\begin{array}{c}0.12 \\
(0.05)^{\text {** }}\end{array}$ \\
\hline Interesting \& challenging & & & & & & 1 & $\begin{array}{r}-0.06 \\
(0.06)\end{array}$ \\
\hline Wants part-time & & & & & & & 1 \\
\hline
\end{tabular}




\section{Appendix: Variables}

wants part-time: dummy variable, 1: individual would like to work part-time

\section{Labor Market Position}

permanent: dummy variable, 1 : individual has a permanent job

temporary: dummy variable, 1 : individual has a temporary job

self employed: dummy variable, 1 : individual is self employed

unemployed: dummy variable, 1: individual is unemployed

out of the labor force: dummy variable, 1 : individual is out of the labor force (students...)

Working Hours

full-time:

part-time:

small part-time:

jobless:

Education

high:

medium:

dummy variable, 1: individual works more than 35 hours per week

dummy variable, 1: individual works between 12 and 35 hours per week

dummy variable, 1 : individual works fewer than 12 hours per week

dummy variable, 1 : individual works zero hours per week

low:

dummy variable, 1 : individual holds an university degree or comparable

dummy variable, 1: individual holds a secondary school diploma (general or vocational)

gender: dummy variable, 1: individual holds a primary school diploma (general

age: or vocational)

Tenure dummy variable, 1 : woman shorter than 1 year:

$1-2$ years:

$2-5$ years:

$5-10$ years:

individual's age (in years)

longer than 10 years: dummy variable, 1 : tenure in present job longer than 10 years

total unemployment dummy variable, 1 : if sum of all unemployment spells longer than 1 year

Labor Market Experience (self reported measure using the following classes)

shorter than 2 years: dummy variable, 1: overall labor market experience shorter than 2 years

$2-5$ years:

$6-10$ years:

11 - 20 years:

dummy variable, 1: 2 to 5 years of labor market experience

longer than 20 years: dummy variable, 1: overall labor market experience longer than 20

years

\section{Households Characteristics}

head: dummy variable, 1: individual is head of the household

spouse: dummy variable, 1: individual is spouse (or living together) of the head of the household

other: dummy variable, 1: individual is the child or other relative of households' member

partner in the household: dummy variable, 1: partner present in the household

breadwinner: dummy variable, 1: individual is the breadwinner in the household

no children: dummy variable, 1: if no children are present in the household

1 child

2 children

dummy variable, 1: if one child living in the household

3 children dummy variable, 1: if two children living in the household dummy variable, 1 : if three children living in the household 
more than 3 children dummy variable, 1: if more than three children live in the household urban type: dummy variable, 1: individual reports him/herself to be an urban type, much or very much

income satisfaction reported degree of satisfaction with one's income (no problem in making ends meet, scale 1 to 5) 
Table A1: Descriptive statistics

wants part-time

\section{Labor Market Position}

permanent job

Temporary job

self employed

unemployed

out of the labor force

Working Hours

full-time

part-time

small part-time

Jobless

Education

high education

medium education

low education

Women

Age

Tenure

shorter than 1 year

1 - 2 years

2 - 5 years

5 - 10 years

more than 10 years

total unemployment

Labor Market Experience

shorter than 1 year

1 - 2 years

2 to 5 years

5 to 10 years

$>10$ years

Households Characteristics

Household head

Other

Spouse

partner in the household

breadwinner

no children

1 child

2 children

3 children

more than 3 children

urban type

financial situation

net monthly income (000)

income squared (/10)
Mean

0.31

0.62

0.09

0.06

0.05

0.19

0.23

0.47

0.23

0.07

0.36

0.45

0.20

0.47

40.12

0.14

0.10

0.16

0.10

0.26

0.15

0.10

0.12

0.16

0.25

0.37

0.60

0.08

0.32

0.81

0.59

0.50

0.14

0.24

0.09

0.03

0.42

3.76

6.42

36.89
Standard

Deviation

0.46

0.49

0.28

0.23

0.22

0.39

0.42

0.50

0.42

0.25

0.48

0.50

0.40

0.50

12.36

0.35

0.30

0.37

0.30

0.44

0.36

0.30

0.33

0.37

0.44

0.48

0.49

0.27

0.47

0.39

0.49

0.50

0.34

0.43

0.29

0.16

0.49

0.95

18.11

524.43 
Appendix 2: Gender and Identity Interaction effects

Table A2: Multivariate probit estimates (*: significant at 10\%, **: significant at 5\%)

\begin{tabular}{|c|c|c|c|c|c|c|c|}
\hline & $\begin{array}{l}\text { Pay } \\
\text { level }\end{array}$ & $\begin{array}{r}\text { Career } \\
\text { opportunities }\end{array}$ & $\begin{array}{r}\text { Training } \\
\text { opportunities }\end{array}$ & $\begin{array}{r}\text { Favorable } \\
\text { work } \\
\text { schedule }\end{array}$ & $\begin{array}{l}\text { Good work } \\
\text { climate }\end{array}$ & $\begin{array}{r}\text { Interesting } \\
\& \\
\text { challenging }\end{array}$ & $\begin{array}{r}\text { Wants } \\
\text { part-time }\end{array}$ \\
\hline work attitude (WA) & $\begin{array}{r}0.05 \\
(0.08)\end{array}$ & $\begin{array}{r}0.04 \\
(0.08)\end{array}$ & $\begin{array}{r}0.13 \\
(0.07)\end{array}$ & $\begin{array}{l}-0.11 \\
(0.07)\end{array}$ & $\begin{array}{r}0.02 \\
(0.08)\end{array}$ & $\begin{array}{c}0.16 \\
(0.10)^{\star *}\end{array}$ & $\begin{array}{r}0.04 \\
(0.11)\end{array}$ \\
\hline work importance (WI) & $\begin{array}{c}0.14 \\
(0.08)\end{array}$ & $\begin{array}{c}0.39 \\
(0.07)^{* \star}\end{array}$ & $\begin{array}{c}0.32 \\
(0.07)\end{array}$ & $\begin{array}{r}0.01 \\
(0.07)\end{array}$ & $\begin{array}{c}0.19 \\
(0.07)^{\star \star}\end{array}$ & $\begin{array}{c}0.32 \\
(0.10)^{\star \star}\end{array}$ & $\begin{array}{l}-0.05 \\
(0.09)\end{array}$ \\
\hline work resistance (WN) & $\begin{array}{r}0.13 \\
(0.08)\end{array}$ & $\begin{array}{l}-0.10 \\
(0.07)\end{array}$ & $\begin{array}{l}-0.05 \\
(0.07)\end{array}$ & $\begin{array}{r}0.06 \\
(0.07)\end{array}$ & $\begin{array}{r}0.14 \\
(0.08)\end{array}$ & $\begin{array}{c}0.25 \\
(0.10)^{\star \star}\end{array}$ & $\begin{array}{r}0.18 \\
(0.10)\end{array}$ \\
\hline Conflicting claims (CC) & $\begin{array}{r}0.01 \\
(0.09)\end{array}$ & $\begin{array}{r}0.23 \\
(0.09)^{\star}\end{array}$ & $\begin{array}{r}0.14 \\
(0.08)\end{array}$ & $\begin{array}{c}0.29 \\
(0.08)^{* *}\end{array}$ & $\begin{array}{r}0.12 \\
(0.08)\end{array}$ & $\begin{array}{r}0.02 \\
(0.11)\end{array}$ & $\begin{array}{r}-0.06 \\
(0.13)\end{array}$ \\
\hline work-home balance & $\begin{array}{r}0.35 \\
(0.11)^{\star \star}\end{array}$ & $\begin{array}{r}0.18 \\
(0.11)\end{array}$ & $\begin{array}{r}0.14 \\
(0.10)\end{array}$ & $\begin{array}{c}0.19 \\
(0.11)^{* *}\end{array}$ & $\begin{array}{r}0.21 \\
(0.11)\end{array}$ & $\begin{array}{r}0.59 \\
(0.13)^{\star \star}\end{array}$ & $\begin{array}{r}0.34 \\
(0.19)\end{array}$ \\
\hline importance of leisure & $\begin{array}{r}0.06 \\
(0.12)\end{array}$ & $\begin{array}{r}-0.09 \\
(0.11)\end{array}$ & $\begin{array}{r}-0.12 \\
(0.11)\end{array}$ & $\begin{array}{c}0.41 \\
(0.11)^{* *}\end{array}$ & $\begin{array}{r}0.14 \\
(0.11)\end{array}$ & $\begin{array}{l}-0.02 \\
(0.13)\end{array}$ & $\begin{array}{c}0.58 \\
(0.22)^{* *}\end{array}$ \\
\hline lack of childcare & $\begin{array}{r}-0.09 \\
(0.25)\end{array}$ & $\begin{array}{l}-0.03 \\
(0.24)\end{array}$ & $\begin{array}{r}0.03 \\
(0.22)\end{array}$ & $\begin{array}{c}0.52 \\
(0.26)^{\star *}\end{array}$ & $\begin{array}{l}-0.24 \\
(0.23)\end{array}$ & $\begin{array}{r}-0.03 \\
(0.27)\end{array}$ & $\begin{array}{r}0.23 \\
(0.25)\end{array}$ \\
\hline Gender & $\begin{array}{r}0.59 \\
(0.59)\end{array}$ & $\begin{array}{r}0.10 \\
(0.59)\end{array}$ & $\begin{array}{l}-0.75 \\
(0.59)\end{array}$ & $\begin{array}{l}-0.24 \\
(0.59)\end{array}$ & $\begin{array}{c}0.22 \\
(0.57)^{* *}\end{array}$ & $\begin{array}{l}-0.05 \\
(0.70)\end{array}$ & $\begin{array}{r}0.44 \\
(0.67)\end{array}$ \\
\hline Labor Market Position & & & & & & & \\
\hline Temporary & $\begin{array}{r}0.08 \\
(0.15)\end{array}$ & $\begin{array}{l}-0.07 \\
(0.13)\end{array}$ & $\begin{array}{l}-0.01 \\
(0.13)\end{array}$ & $\begin{array}{l}-0.16 \\
(0.13)\end{array}$ & $\begin{array}{l}-0.17 \\
(0.14)\end{array}$ & $\begin{array}{r}0.01 \\
(0.17)\end{array}$ & $\begin{array}{r}0.13 \\
(0.16)\end{array}$ \\
\hline self-employed & $\begin{array}{r}0.17 \\
(0.16)\end{array}$ & $\begin{array}{l}-0.12 \\
(0.14)\end{array}$ & $\begin{array}{r}0.07 \\
(0.14)\end{array}$ & $\begin{array}{l}-0.17 \\
(0.14)\end{array}$ & $\begin{array}{r}0.07 \\
(0.16)\end{array}$ & $\begin{array}{l}-0.02 \\
(0.16)\end{array}$ & $\begin{array}{r}0.20 \\
(0.19)\end{array}$ \\
\hline unemployed & $\begin{array}{l}-0.25 \\
(0.19)\end{array}$ & $\begin{array}{l}-0.47 \\
(0.19)^{* *}\end{array}$ & $\begin{array}{l}-0.13 \\
(0.18)\end{array}$ & $\begin{array}{r}-0.00 \\
(0.20)\end{array}$ & $\begin{array}{r}-0.21 \\
(0.19)\end{array}$ & $\begin{array}{l}-0.49 \\
(0.21) *\end{array}$ & $\begin{array}{c}1.73 \\
(0.21)\end{array}$ \\
\hline non-participating & $\begin{array}{c}-0.07 \\
(0.15)\end{array}$ & $\begin{array}{c}-0.10 \\
(0.14)\end{array}$ & $\begin{array}{r}0.02 \\
(0.13)\end{array}$ & $\begin{array}{r}0.15 \\
(0.14)\end{array}$ & $\begin{array}{c}-0.27 \\
(0.15)\end{array}$ & $\begin{array}{r}-0.51 \\
(0.17)^{\star \star}\end{array}$ & $\begin{array}{c}1.29 \\
(0.18)\end{array}$ \\
\hline
\end{tabular}




\begin{tabular}{|c|c|c|c|c|c|c|c|}
\hline Employed*part-time & $\begin{array}{l}-0.50 \\
(0.15)\end{array}$ & $\begin{array}{l}-0.16 \\
(0.15)\end{array}$ & $\begin{array}{r}0.07 \\
(0.14)\end{array}$ & $\begin{array}{r}0.20 \\
(0.15)\end{array}$ & $\begin{array}{r}0.01 \\
(0.15)\end{array}$ & $\begin{array}{r}-0.40 \\
(0.17)^{\star}\end{array}$ & $\begin{array}{c}1.51 \\
(0.18)^{\star \star}\end{array}$ \\
\hline \multirow[t]{2}{*}{ Employed*small part-time } & -0.25 & -0.30 & -0.07 & 0.26 & 0.00 & -0.43 & 1.81 \\
\hline & $(0.25)$ & $(0.22)$ & $(0.23)$ & $(0.22)$ & $(0.24)$ & $(0.24)$ & $(0.26)^{\star \star}$ \\
\hline \multicolumn{8}{|l|}{ Tenure } \\
\hline \multirow[t]{2}{*}{1 - 2 years } & 0.01 & 0.09 & -0.00 & -0.14 & -0.10 & -0.10 & 0.14 \\
\hline & $(0.14)$ & $(0.13)$ & $(0.12)$ & $(0.13)$ & $(0.14)$ & $(0.15)$ & $(0.17)$ \\
\hline \multirow[t]{2}{*}{3 to 5 years } & 0.05 & -0.16 & -0.13 & -0.17 & -0.11 & 0.01 & 0.23 \\
\hline & $(0.15)$ & $(0.13)$ & $(0.13)$ & $(0.14)$ & $(0.14)$ & $(0.17)$ & $(0.17)$ \\
\hline \multirow[t]{2}{*}{6 to 10 years } & 0.06 & 0.04 & 0.03 & -0.20 & 0.02 & -0.02 & 0.29 \\
\hline & $(0.13)$ & $(0.12)$ & $(0.11)$ & $(0.12)$ & $(0.12)$ & $(0.16)$ & $(0.16)$ \\
\hline \multirow[t]{2}{*}{$>10$ years } & -0.05 & -0.21 & -0.13 & -0.35 & -0.24 & -0.16 & 0.23 \\
\hline & $(0.13)$ & $(0.12)$ & $(0.12)$ & $(0.12)^{\star \star}$ & $(0.13)$ & $(0.16)$ & $(0.17)$ \\
\hline \multicolumn{8}{|l|}{ Education } \\
\hline \multirow[t]{2}{*}{ Primary } & 0.07 & -0.06 & -0.15 & 0.23 & 0.08 & -0.21 & 0.02 \\
\hline & $(0.10)$ & (0.09) & $(0.09)$ & $(0.10)^{\star \star}$ & $(0.09)$ & $(0.10) \star \star$ & (0.11) \\
\hline \multirow[t]{2}{*}{ university \& hbo } & 0.03 & 0.09 & 0.11 & -0.04 & 0.10 & 0.26 & 0.03 \\
\hline & $(0.08)$ & $(0.08)$ & $(0.07)$ & $(0.08)$ & $(0.08)$ & $(0.10)^{\star \star}$ & $(0.09)$ \\
\hline \multicolumn{8}{|l|}{ Workers Characterisitics } \\
\hline \multirow[t]{2}{*}{ Age } & -0.05 & -0.07 & -0.03 & -0.00 & 0.02 & -0.03 & 0.09 \\
\hline & $(0.03)$ & $(0.03)^{\star}$ & $(0.03)$ & $(0.03)$ & $(0.03)$ & $(0.03)$ & $(0.03)^{\star *}$ \\
\hline \multirow[t]{2}{*}{ age squared } & 0.00 & 0.00 & 0.00 & 0.00 & -0.00 & 0.00 & -0.00 \\
\hline & $(0.00)$ & $(0.00)^{\star}$ & $(0.00)$ & $(0.00)$ & $(0.00)$ & $(0.00)$ & $(0.00)^{\star \star}$ \\
\hline \multirow[t]{2}{*}{ total unemployment } & -0.15 & 0.01 & -0.00 & 0.01 & 0.03 & -0.00 & 0.15 \\
\hline & $(0.10)$ & $(0.10)$ & $(0.10)$ & (0.11) & $(0.10)$ & $(0.12)$ & $(0.12)$ \\
\hline \multirow[t]{2}{*}{ Income } & 0.00 & -0.01 & -0.01 & 0.00 & -0.00 & 0.00 & -0.00 \\
\hline & $(0.00)$ & $(0.01)$ & $(0.01)$ & $(0.01)$ & $(0.00)$ & $(0.00)$ & $(0.01)$ \\
\hline \multirow[t]{2}{*}{ income squared } & -0.01 & 0.10 & 0.05 & 0.03 & 0.00 & -0.01 & 0.00 \\
\hline & $(0.01)$ & $(0.06)$ & $(0.05)$ & $(0.05)$ & $(0.01)$ & $(0.01)$ & $(0.01)$ \\
\hline \multicolumn{8}{|l|}{ Labor Market Experience } \\
\hline \multirow{2}{*}{1 - 2 years } & -0.34 & -0.17 & 0.18 & -0.10 & -0.10 & -0.09 & -0.02 \\
\hline & $(0.19)$ & $(0.18)$ & $(0.18)$ & $(0.20)$ & $(0.19)$ & $(0.20)$ & $(0.22)$ \\
\hline 2 to 5 years & -0.33 & 0.03 & -0.00 & 0.04 & 0.15 & -0.08 & -0.53 \\
\hline
\end{tabular}




\begin{tabular}{|c|c|c|c|c|c|c|c|}
\hline & $(0.16)^{\star \star}$ & $(0.15)$ & $(0.15)$ & $(0.16)$ & $(0.16)$ & $(0.18)$ & $(0.18)^{\star \star}$ \\
\hline \multirow[t]{2}{*}{5 to 10 years } & -0.22 & -0.10 & 0.11 & 0.15 & 0.02 & -0.01 & -0.31 \\
\hline & $(0.14)$ & $(0.13)$ & $(0.13)$ & $(0.14)$ & $(0.14)$ & $(0.16)$ & $(0.16)^{\star \star}$ \\
\hline \multirow[t]{2}{*}{$>10$ years } & -0.05 & 0.04 & 0.00 & 0.07 & 0.09 & -0.10 & -0.06 \\
\hline & $(0.11)$ & $(0.10)$ & $(0.10)$ & $(0.11)$ & $(0.10)$ & $(0.12)$ & $(0.12)$ \\
\hline \multicolumn{8}{|c|}{ Household Characteristics } \\
\hline \multirow[t]{2}{*}{ head } & -0.07 & 0.14 & -0.17 & 0.28 & -0.00 & 0.32 & 0.08 \\
\hline & $(0.18)$ & $(0.15)$ & $(0.17)$ & $(0.16)$ & $(0.17)$ & $(0.20)$ & $(0.19)$ \\
\hline \multirow[t]{2}{*}{ other } & -0.26 & -0.23 & -0.03 & -0.28 & 0.02 & -0.13 & -0.11 \\
\hline & $(0.23)$ & $(0.22)$ & $(0.21)$ & $(0.22)$ & $(0.23)$ & $(0.27)$ & $(0.26)$ \\
\hline \multirow[t]{2}{*}{ spouse present } & 0.01 & 0.03 & -0.03 & 0.18 & -0.10 & -0.09 & 0.22 \\
\hline & $(0.12)$ & $(0.11)$ & $(0.11)$ & $(0.11)$ & $(0.11)$ & $(0.14)$ & $(0.15)$ \\
\hline \multirow[t]{2}{*}{ breadwinner } & 0.19 & -0.05 & 0.24 & -0.19 & -0.06 & -0.38 & -0.10 \\
\hline & $(0.18)$ & $(0.15)$ & $(0.17)$ & $(0.16)$ & $(0.17)$ & $(0.20)$ & $(0.19)$ \\
\hline \multirow[t]{2}{*}{1 child } & 0.07 & -0.06 & -0.28 & 0.04 & -0.06 & -0.03 & -0.07 \\
\hline & $(0.12)$ & $(0.11)$ & $(0.11)^{\star}$ & $(0.12)$ & $(0.11)$ & $(0.13)$ & $(0.14)$ \\
\hline \multirow[t]{2}{*}{2 children } & 0.23 & 0.03 & -0.14 & 0.25 & -0.03 & 0.11 & 0.19 \\
\hline & $(0.11)^{\star}$ & $(0.10)$ & $(0.10)$ & $(0.11)^{\star}$ & $(0.11)$ & $(0.12)$ & $(0.12)$ \\
\hline \multirow[t]{2}{*}{3 children } & -0.07 & 0.03 & -0.11 & -0.14 & -0.10 & -0.09 & 0.14 \\
\hline & $(0.14)$ & $(0.14)$ & $(0.13)$ & $(0.14)$ & $(0.14)$ & $(0.16)$ & $(0.16)$ \\
\hline \multirow[t]{2}{*}{$>3$ children } & -0.28 & -0.35 & -0.43 & 0.26 & -0.08 & -0.19 & 0.22 \\
\hline & $(0.21)$ & $(0.20)$ & $(0.19)^{\star}$ & $(0.23)$ & $(0.22)$ & $(0.21)$ & $(0.23)$ \\
\hline \multirow[t]{2}{*}{ city type } & -0.03 & 0.03 & -0.02 & -0.10 & -0.11 & -0.01 & -0.15 \\
\hline & (0.08) & $(0.07)$ & $(0.07)$ & $(0.08)$ & $(0.07)$ & $(0.09)$ & $(0.09)$ \\
\hline \multirow[t]{2}{*}{ financial situation } & 0.22 & 0.22 & 0.14 & 0.13 & 0.29 & 0.20 & 0.00 \\
\hline & $(0.08)^{\star *}$ & $(0.08) \star \star$ & $(0.07)^{\star *}$ & $(0.08)^{*}$ & $(0.08)^{* *}$ & $(0.09) \star \star$ & $(0.09)$ \\
\hline Provinces (11 dummies) & YES & YES & YES & YES & YES & YES & YES \\
\hline \multicolumn{8}{|c|}{ interaction terms: gender $x$} \\
\hline \multirow[t]{2}{*}{ work attitude (WA) } & -0.17 & 0.03 & 0.19 & 0.12 & 0.00 & 0.16 & 0.13 \\
\hline & $(0.12)$ & $(0.11)$ & $(0.11)$ & $(0.12)$ & $(0.12)$ & $(0.14)$ & $(0.14)$ \\
\hline \multirow[t]{2}{*}{ work importance (WI) } & -0.00 & 0.01 & 0.10 & -0.01 & 0.06 & 0.05 & -0.11 \\
\hline & $(0.10)$ & $(0.10)$ & (0.09) & $(0.10)$ & $(0.10)$ & $(0.12)$ & $(0.12)$ \\
\hline work resistance (WN) & -0.13 & 0.06 & 0.01 & 0.01 & -0.05 & -0.17 & -0.17 \\
\hline
\end{tabular}




\begin{tabular}{|c|c|c|c|c|c|c|c|}
\hline & $(0.12)$ & $(0.10)$ & $(0.11)$ & $(0.12)$ & $(0.11)$ & $(0.15)$ & $(0.13)$ \\
\hline \multirow[t]{2}{*}{ conflicting claims (CC) } & 0.12 & -0.23 & -0.10 & 0.00 & -0.02 & 0.04 & 0.34 \\
\hline & $(0.13)$ & $(0.12)^{\star \star}$ & $(0.12)$ & $(0.13)$ & $(0.12)$ & $(0.15)$ & $(0.16)^{\star *}$ \\
\hline \multirow[t]{2}{*}{ work-home balance } & -0.20 & -0.18 & -0.09 & 0.14 & -0.18 & -0.48 & -0.16 \\
\hline & $(0.17)$ & $(0.15)$ & $(0.14)$ & $(0.16)$ & $(0.16)$ & $(0.18)^{\star \star}$ & $(0.22)$ \\
\hline \multirow[t]{2}{*}{ Importance of leisure } & 0.05 & 0.09 & 0.26 & 0.06 & 0.15 & 0.21 & -0.33 \\
\hline & $(0.17)$ & $(0.16)$ & $(0.15)$ & $(0.16)$ & $(0.16)$ & (0.19) & $(0.25)$ \\
\hline \multirow[t]{2}{*}{ lack of childcare } & 0.04 & -0.03 & -0.00 & -0.26 & 0.20 & -0.08 & -0.06 \\
\hline & $(0.29)$ & $(0.26)$ & $(0.25)$ & $(0.30)$ & $(0.27)$ & $(0.31)$ & $(0.28)$ \\
\hline \multirow[t]{2}{*}{ employed*part-time } & 0.48 & 0.12 & -0.13 & 0.26 & 0.05 & 0.04 & -0.15 \\
\hline & $(0.19) * \star$ & (0.18) & (0.18) & $(0.19)$ & $(0.19)$ & $(0.22)$ & $(0.21)$ \\
\hline \multirow[t]{2}{*}{ employed*small part-time } & -0.10 & 0.14 & 0.01 & 0.46 & -0.13 & -0.09 & -0.49 \\
\hline & $(0.29)$ & $(0.26)$ & $(0.27)$ & $(0.28)$ & $(0.28)$ & $(0.29)$ & $(0.29)$ \\
\hline \multirow[t]{2}{*}{ Constant } & 1.00 & 0.39 & -0.72 & -0.48 & -1.30 & -0.11 & -5.22 \\
\hline & $(0.73)$ & $(0.74)$ & $(0.73)$ & $(0.76)$ & $(0.76)$ & $(0.88)$ & $(0.92)^{\star \star}$ \\
\hline observations & & & & 1828 & & & \\
\hline restricted model & & & & -6172 & & & \\
\hline full model & & & & -5552 & & & \\
\hline \multirow[t]{2}{*}{ Likelihood ratio test: chi2 } & & & & 1240 ** & & & \\
\hline & & & & Favorable & & Interesting & \\
\hline \multirow{2}{*}{ CORRELATION MATRIX } & Pay & Career & Training & work & Good work & & Wants \\
\hline & level & opportunities & opportunities & schedule & climate & challenging & part-time \\
\hline \multirow[t]{2}{*}{ Pay level } & 1 & 0.56 & 0.35 & 0.45 & 0.36 & 0.53 & 0 \\
\hline & & $(0.04) * \star$ & $(0.04) * *$ & $(0.04)^{\star *}$ & $(0.04) * *$ & $(0.04)^{\star *}$ & $(0.05)$ \\
\hline \multirow[t]{2}{*}{ Career opportunities } & & 1 & 0.58 & 0.32 & 0.29 & 0.57 & -0.12 \\
\hline & & & $(0.03) * *$ & $(0.04)^{\star *}$ & $(0.04)^{* *}$ & $(0.04)^{\star *}$ & $(0.05)^{\star \star}$ \\
\hline \multirow[t]{2}{*}{ Training opportunities } & & & 1 & 0.18 & 0.27 & 0.8 & -0.1 \\
\hline & & & & $(0.04)^{\star \star}$ & $(0.04)^{\star \star}$ & $(0.03)^{\star *}$ & $(0.05)^{\star \star}$ \\
\hline \multirow[t]{2}{*}{ Favorable working hours } & & & & 1 & 0.38 & 0.48 & 0.15 \\
\hline & & & & & $(0.04) * *$ & $(0.05)^{\star \star}$ & $(0.05)^{\star \star}$ \\
\hline \multirow[t]{2}{*}{ Good work climate } & & & & & 1 & 0.63 & 0.12 \\
\hline & & & & & & $(0.04)^{\star \star}$ & $(0.05)^{\star \star}$ \\
\hline
\end{tabular}


The reference group of the variables is given in parentheses: Employment Status (voluntary full-time), Labor-Market Position (permanent job), Total Unemployment (shorter than 1 year), Educational Level (medium), Gender (male)), Tenure (1 year or less), Position in the Household (not married), Spouse in the Household (no spouse in the

household), breadwinner (not bread winner), Province (Limburg), work experience (1 year or less), number of children (no children), city type (does not want to live in city). 